\title{
Why is Palliative Care Training During the Portuguese Family Medicine Residency Program Not Mandatory?
}

\section{Porque é que a Formação em Cuidados Paliativos no Internato de Medicina Geral e Familiar em Portugal Não é Obrigatória?}

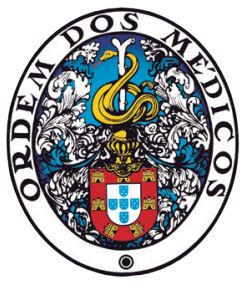

\author{
Raquel F. CASTRO $\triangle^{1}$, Ana Catarina ESTEVES ${ }^{2}$, Maria GOUVEIA ${ }^{3}$, Paulo REIS-PINA ${ }^{4,5,6}$
}

Acta Med Port 2022 Feb;35(2):87-88 - https://doi.org/10.20344/amp.14638

Keywords: Family Medicine; Family Physician; Internship and Residency; Medical Education; Palliative Care; Primary Health Care

Palavras-chave: Cuidados Paliativos; Cuidados de Saúde Primários; Educação Médica; Internato Médico; Medicina Geral e Familiar

The Portuguese Family Medicine residency program lasts four years and consists in a number of both mandatory and elective internships, of variable duration. The elective training periods can be decided by residents with the agreement of both the respective trainers and residency bodies, after taking in consideration its relevance and feasibility. Residency training bodies also organize some in-house short courses on specific topics. ${ }^{1}$

One important characteristic of the discipline of Family Medicine is longitudinal care of patients throughout their lives. Because of the ageing population and their increased complexity, it is expected that family physicians will increasingly provide palliative measures to their patients. ${ }^{2}$ Therefore, we consider that palliative care training is essential for the resident's growth as a family physician. Even though the current training program is already trying to raise awareness of training in palliative care, there is still no mandatory training during residency. ${ }^{1}$

We believe that a vulnerable human being at the endof-life can require as much attention as a vulnerable human being after birth. The particularities of those who have disabling and progressive diseases could be just as significant as those who are born and thrive, but doctors must be aware of that. With this in mind, we intend to reflect on the advantages and disadvantages of including mandatory training in palliative care in the Portuguese Family Medicine residency program. Family Medicine is a complex medical specialty that requires considerable training in multiple fields. We realize that it is unrealistic to provide family physicians with advanced training in all the relevant fields. For example, there are many highly prevalent diseases in which family physicians do not have mandatory training, such as cardiovascular diseases; however, due to their high prevalence and widespread availability of training opportunities, family physicians end up being well prepared to treat these patients. Despite the high prevalence of palliative needs in the community, there are not many training opportunities in this area provided by trainers, residency training bodies, or others. Nevertheless, palliative care training exists but is mostly available as a diploma, master's, or PhD programmes, which means a more intense and expensive education altogether but probably not as suitable for the needs of Family Medicine residents or specialists.

Family physicians are in a privileged position to identify patients in need of palliative care since they normally follow their patients and families throughout time, do home visits and are usually the first point of contact for patients. ${ }^{3}$ Moreover, they also help patients navigate the healthcare system and may be required to assist their patients in endof-life decisions. ${ }^{3}$ According to Aguiar, ${ }^{4}$ approximately $1 \%$ of patients in a family physician's patients list will be terminally ill each year. The early identification of these patients and their palliative needs is important as it can lead to the improvement of quality of life by the provision of better and early symptom control and the anticipation of the needs and wishes of both patients and families. ${ }^{3,5}$ But for the purposes of early identification, physicians must be aware of which patients may need palliative care. ${ }^{5}$ The lack of training in this field is one of the main barriers to the provision of Palliative Care by family physicians and may justify a certain lack of confidence regarding the clinical management of increasingly older and complex patients. ${ }^{2,3,6}$ Moreover, excessive bureaucracy, lack of time, resources and communication between primary and secondary health care and high patient complexity, were also mentioned as difficulties. ${ }^{3,6}$ Despite these barriers, family physicians improved their abilities, identified more patients with palliative needs and applied more palliative measures after receiving

\footnotetext{
1. Unidade de Saúde Familiar Reynaldo dos Santos. Agrupamento de Centros de Saúde Estuário do Tejo. Administração Regional de Saúde Lisboa e Vale do Tejo. Póvoa de Santa Iria. Portugal.

2. Unidade de Saúde Familiar Conde de Oeiras. Agrupamento de Centros de Saúde Lisboa Ocidental e Oeiras. Administração Regional de Saúde Lisboa e Vale do Tejo. Oeiras. Portugal.

3. Unidade de Cuidados de Saúde Personalizados de Alcântara. Agrupamento de Centros de Saúde Lisboa Ocidental e Oeiras. Administração Regional de Saúde Lisboa e Vale do Tejo. Lisboa. Portugal.
}

4. Unidade de Cuidados Paliativos. Casa da Saúde da Idanha. Sintra. Portugal.

5. Faculdade de Medicina. Universidade do Minho. Braga. Portugal.

6. Faculdade de Medicina. Universidade de Lisboa. Lisboa. Portugal.

$\square$ Autor correspondente: Raquel F. Castro. raquelcastromgf@gmail.com

Recebido: 27 de julho de 2020 - Aceite: 01 de maio de 2021 - First published: 17 de setembro de 2021 - Online issue published: 01 de fevereiro de 2022 Copyright @ Ordem dos Médicos 2022 
training in palliative care. ${ }^{7}$ In fact, family physicians believe that they can have an important role in the follow up of patients with palliative needs. ${ }^{2,3,8}$ This data shows that it is essential to provide training in palliative care to family physicians in order to improve end-of-life care.

We also believe it would be extremely important that family physicians learn how to define an advanced care plan for their patients proactively, how to anticipate and relieve the suffering of patients and families, how to avoid recurrent trips to hospital and how to provide a death at home if it is the patient's desire.

National initiatives, such as the Portuguese Strategic Plan for Palliative Care Development, mention that family physicians are responsible for the follow-up of patients with low to moderate complexity and should have postgraduate education lasting between 90 and 280 hours. ${ }^{7}$ Moreover, international guidelines, such as those from the World Health Organization, mention that palliative care should work in partnership and be incorporated into existing healthcare services. ${ }^{9}$

Considering the lack of training in palliative care during residency and evidence showing that lack of training equals lack of palliative care in the community, how could this aspect be improved? We suggest a change to the Portuguese Family Medicine residency program by the inclusion of a mandatory 30-hour palliative care theoretical course, organized by each Regional Health Administration, during the third or fourth year of residency as well as mandatory practical training for two to four weeks.

We feel that any form of practical training should be organized nationwide depending on the availability of host organizations, such as the Community Palliative Care Support teams (preferably), the hospices and the hospital-based palliative care support teams, to receive family medicine residents. By doing so, we do not expect the need to extend the duration of the Family Medicine residency program.

With this proposal, our main goal is to defend the need for basic training so that family physicians are able to: identify patients with palliative needs, treat the most common

\section{REFERENCES}

1. Portugal. Portaria $n^{\circ} 125 / 2019$ de 30 de abril. Diário da República $n^{\circ}$ 83/2019, Série I. [accessed 2020 Jul 01]. Available from: https://dre.pt/ home/-/dre/122195237/details/maximized.

2. Sarmiento Medina P, Díaz Prada V, Rodriguez $N$. The role of the family doctor in the palliative care of chronic and terminally ill patients. Semergen. 2019;45:349-55.

3. Ramanayake R, Dilanka G, Premasiri L. Palliative care; role of family physicians. J Family Med Prim Care. 2016;5:234-7.

4. Aguiar $\mathrm{H}$. Os cuidados paliativos nos cuidados de saúde primários - $\mathrm{O}$ desafio para o século XXI. Rev Port Med Geral Fam. 2012;28:442-7.

5. EIMokhallalati Y, Bradley SH, Chapman E, Ziegler L, Murtagh FE, Johnson MJ, et al. Identification of patients with potential palliative care needs: a systematic review of screening tools in primary care. Palliat Med. 2020;34:989-1005.

6. Le B, Eastman P, Vij S, McCormack F, Duong C, Philip J. Palliative care symptoms and refer the most complex situations to specialized palliative care teams.

In conclusion, family physicians develop a trust-based relationship with their patients and families that empowers them with the ability to practice palliative care. Family physicians, as care managers, need to have extensive knowledge ('to know'), abilities ('to do'), and skills ('make happen') to be able to follow their patients and families efficiently. Family physicians are the patients' health managers and bear the responsibility to defend their human dignity: in the beginning, during and in the end-of-life. So, wouldn't it be valuable to have mandatory palliative care training during the Family Medicine residency program in Portugal?

\section{AUTHORS CONTRIBUTION}

All the authors contributed equally to the conception of the work, the critical review of the manuscript and the final approval of the version to be published.

\section{PROTECTION OF HUMANS AND ANIMALS}

The authors declare that the procedures were followed according to the regulations established by the Clinical Research and Ethics Committee and to the Helsinki Declaration of the World Medical Association updated in 2013.

\section{DATA CONFIDENTIALITY}

The authors declare having followed the protocols in use at their working center regarding patients' data publication.

\section{COMPETING INTERESTS}

The authors have declared that no competing interests exist.

\section{FUNDING SOURCES}

This research received no specific grant from any funding agency in the public, commercial, or not-for-profit sectors.

in general practice: GP integration in caring for patients with advanced cancer. Aust Fam Physician. 2017;46:51-5.

7. Comissão Nacional de Cuidados Paliativos. Plano Estratégico para o Desenvolvimento de Cuidados Paliativos, Biénio 2019-2020; 2019 [accessed $2020 \mathrm{Jul}$ 01]. Available from: https://www.sns.gov.pt/wp-content/ uploads/2019/04/PEDCP-2019-2020-versao-final-10.02.2019.pdf.

8. Peter S, Volkert AM, Pfaff H, Radbruch L, Rolke R, Voltz R, et al. General practitioners' perspectives on general and specialized palliative home care in North Rhine, Germany: an explorative focus Group Study. Am J Hosp Palliat Care. 2020;1049909120920541.

9. World Health Organization. WHO Assembly, 67. Strengthening of palliative care as a component of integrated treatment throughout the life course: report by the Secretariat; 2014 [accessed 2020 Jul 12]. Available from: https://apps.who.int/iris/handle/10665/158962. 